\title{
Pemanfaatan Biomassa Enceng Gondok Dari Danau Limboto Sebagai Penghasil Biogas
}

Julhim S. Tangio

Program Studi Pendidikan Kimia, FMIPA Universitas Negeri Gorontalo

\section{${ }^{*}$ Corresponding author:}

email:

julhimstangio@ung.ac.id

Received: 18 March, 2019

Accepted: 19 March, 2019

Online : 20 March, 2019
Abstract. The purpose of this study is to study the potential of water hyacinth in producing biogas. In this study, it was studied how to make biogas with the addition of biostarter $1.25 \mathrm{~g}$ of cow dung compared to controls without a biostater. Besides that, it also examines how to make biogas using snail intestinal biostarter. The addition of biostarter amounts to $50 \mathrm{~g}$ of cow dung. The treatment of acid hydrolysis against the water hyacinth substrate and without biostarter and the treatment of acid hydrolysis and addition of biostarter $1.25 \mathrm{~g}$ cow dung. The results of the study were obtained at the initial stage of research, in the TAK (No Control Acidification) reactor formed at $29 \mathrm{~mL}$, TAS reactor (without acidification with cow manure biostater) of $50 \mathrm{~mL}$ and $T A B$ reactor (without acidification with snail intestinal biostater) of $30 \mathrm{~mL}$. The advanced stage with the addition of acid and the addition of 1: 1 biostater the results obtained at the KS (Cow Manure) reactor were $102 \mathrm{~mL}$ and the $S D$ reactor was $5 \mathrm{~mL}$.

Keywords: Hyacinth, biogas, anaerobic digestion, acid hydrolysis

Abstrak. Tujuan penelitian ini adalah untuk mengkaji potensi enceng gondok tersebut dalam menghasilkan biogas. Dalam penelitian ini dikaji bagaimana pembuatan biogas dengan penambahan biostarter $1,25 \mathrm{~g}$ kotoran sapi dibandingkan kontrol tanpa biostater. Disamping itu juga mengkaji bagaimana pembuatan biogas dengan mengunakan biostarter usus bekicot. Penambahan jumlah biostarter menjadi $50 \mathrm{~g}$ kotoran sapi. Adanya perlakuan hidrolisis asam terhadap substrat enceng gondok dan tanpa biostarter dan adanya perlakuan hidrolisis asam dan penambahan biostarter 1,25 g kotoran sapi. Hasil penelitian diperoleh pada peneltian tahap awal, pada reaktor TAK (Tanpa Pengasaman Kontrol) biogas terbentuk sebesar $29 \mathrm{~mL}$, reaktor TAS (Tanpa Pengasaman dengan Biostater Kotoran Sapi) sebesar $50 \mathrm{~mL}$ dan reaktor TAB (Tanpa Pengasaman dengan Biostater usus Bekicot) sebesar $30 \mathrm{~mL}$. Pada tahap lanjutan dengan penambahan asam dan penambahan biostater 1:1 diperoleh hasil pada reaktor KS (Kotoran Sapi) sebesar $102 \mathrm{~mL}$ dan reaktor SD sebesar $5 \mathrm{~mL}$.

Kata Kunci: Enceng gondok, biogas, anaerobic digestion, hidrolisis asam

\section{PENDAHULUAN}

Salah satu tanaman air yang pertumbuhannya sangat cepat adalah enceng gondok. Pertumbuhan yang sangat cepat ini menyebabkan enceng gondok dengan cepat pula menutupi permukaan air danau sehingga keberadaanya dianggap sebagai gulma. Terlebih lagi pada kondisi lingkungan yang tinggi nutrien seperti limbah domestik. Enceng gondok juga mempunyai sistem perakaran yang luas, hal ini sangat baik untuk media pendukung pertumbuhan mikroorganisme (Zimmels, dkk, 2006) dalam Saputri dan Trihadiningrum. Namun umumnya, enceng gondok sebagai gulma ini pemanfaatannya sangat kecil. Salah satu pemanfaatan dari enceng gondok yang dilakukan saat ini adalah batangnya dijadikan sebagai perabotan seperti kursi, tetapi pemanfaatannya belum maksimal. Hal ini dikarenakan peminat pasar masih kurang dan belum diketahui banyak orang. Enceng gondok merupakan salah satu sumber biomassa yang mengandung 
hemiselulosa yang sangat besar sehingga baik dimanfaatkan menjadi sumber energi alternatif. Misalnya sebagai bahan baku pembuatan biogas. Keberadaan enceng gondok di Danau Limboto saat ini sangat melimpah dan belum dimanfaatkan secara maksimal.

Biogas merupakan gas yang dapat dijadikan bahan bakar alternatif untuk menggantikan bahan bakar yang berasal dari fosil seperti minyak tanah dan gas alam (Said, $H$. 1999). Biogas juga sebagai salah satu jenis bioenergi yang didefinisikan sebagai gas yang dilepaskan jika bahan- bahan organik seperti kotoran ternak, kotoran manusia, jerami, sekam dan daun-daun hasil sortiran sayur difermentasi atau mengalami proses metanisasi (Hambali, E. 2008). Biogas adalah suatu jenis gas yang bisa dibakar, yang diproduksi melalui proses fermentasi anaerobik bahan organik seperti kotoran ternak dan manusia, biomassa limbah pertanian atau campuran keduanya, didalam suatu ruang pencerna (digester).

Akibat penggunaan bahan bakar fosil (fuel fosil) dalam jangka panjang ternyata telah memberikan implikasi negatif terhadap kehidupan di dunia. penggunaan bahan bakar fosil seperti minyak bumi, batu bara dan gas alam telah menyumbangkan cukup besar emisi gas efek rumah kaca yaitu karbon dioksida ke atmosfer bumi yang ikut andil dalam proses pemanasan global (global warming). Pemanasan global memberikan dampak sangat negatif dan memprihatinkan pada stabilitas kehidupan manusia antara lain menyebabkan iklim tidak stabil, peningkatan suhu permukaan laut, suhu global dunia akan cenderung meningkat, gangguan ekologis serta berdampak pada kerusakan lingkungan dan pada kehidupan. Melihat implikasi negatif dari penggunaan bahan bakar fosil terhadap lingkungan dan keterbatasan persediaan cadangan BBM telah mendorong kepada pencarian sumber energi alternatif yang diharapakan juga ramah lingkungan dan bersifat dapat diperbaharui (renewable).

Pemanfaatan biogas di Indonesia sebagai energi alternatif sangat memungkinkan untuk diterapkan di masyarakat. Besarnya potensi limbah biomassa padat di seluruh Indonesia seperti kayu dari kegiatan industri pengolahan hutan, pertanian dan perkebunan; limbah kotoran hewan, misalnya kotoran sapi, kerbau, kuda, dan babi juga dijumpai di seluruh provinsi Indonesia dengan kualitas yang berbeda-beda. (Simamora, 2008)
Eceng gondok dan limbah kotoran sapi sebagai sumber $\mathrm{C}$ dan $\mathrm{N}$ dalam pembuatan biogas mempengaruhi pembentukan gas metan. Menurut Astuti, N., dkk (2013) rasio C/N dalam eceng gondok di Rawapening sebesar 10,8. sedangkan rasio $\mathrm{C} / \mathrm{N}$ dalam limbah kotoran sapi sebesar 22,97. Suhu selama waktu fermentasi optimal pada hari ke 20 dengan suhu $32^{\circ} \mathrm{C}$ serta pH mengalami penurunan dari awal sampai akhir waktu fermentasi. Selanjutnya menurut Karkit dan Gautam (1994), bahan dengan C/N rasio tinggi dapat dipadukan dengan bahan yang memiliki $\mathrm{C} / \mathrm{N}$ rasio yang rendah sehingga di peroleh ratarata perbandingan $\mathrm{C} / \mathrm{N}$ rasio antara $20-30$.

\section{METODOLOGI PENELITIAN}

\section{Waktu dan Lokasi Penelitian}

Penelitian ini dilakukan selama 6 bulai mulai bulan Maret sampai Agustus 2014 yang bertempat di laboratorium Kimia Universitas Negeri Gorontalo

\section{Desain Penelitian}

Desain dalam penelitian ini adalah menggunakan analisis kuantitatif terhadap biogas yang dihasilkan dari sampel dengan sistem anaerob digester air.

\section{Alat dan Bahan yang digunakan}

\section{Persiapan Alat}

Alat yang digunakan adalah seperangkat reaktor anaerobic mengunakan reaktor batch dengan kapasitas $250 \mathrm{~mL}$ sebanyak 12 buah. Reaktor berupa erlenmeyer $250 \mathrm{~mL}$ yang ditutup dengan karet berselang yang dihubungkan ke gelas ukur $50 \mathrm{~mL}$ untuk pengamatan penurunan air atau larutan kapur yang ada dalam gelas ukur akibat terbentuknya biogas. Alat yang digunakan adalah gelas ukur, Termometer, Selang, Erlenmeyer dan gelas kimia. Alat-alat yang ada kemudian dirangkai menjadi reaktor batch yang dikenal dengan reaktor bacth anaerob digester air. Gambar reaktor dapat dilihat pada gambar 1 .

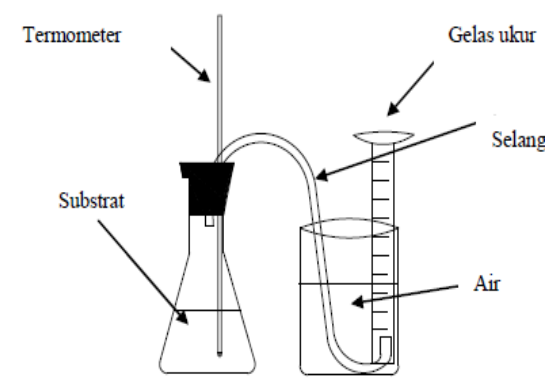

Gambar 1. Reaktor Batch Anaerobik Digester Air 


\section{Persiapan Bahan}

1. Penyediaan enceng gondok. Enceng gondok diambil langsung dari danau Limboto Kabupaten Gorontalo. Setelah itu seluruh bagian enceng gondok (akar, batang, dan daun) dicacah hingga berukuran kecil-kecil. Setiap reaktor menggunakan $50 \mathrm{~g}$ enceng gondok (dalam berat basah) kemudian diblender dan ditambahkan air sesuai variabel komposisi yang akan digunakan pada penelitian pendahuluan.

2. Penyediaan Kotoran Sapi dan usus bekicot

Kotoran sapi diambil dari peternak sapi petani. Kotoran sapi ini dicampur dengan enceng gondok yang sudah diblender sebagai biostarter. Sedangkan bekicot diambil dari sawah.

\section{Rancangan Penelitian}

Dalam penelitian ini akan digunakan tiga variabel, yaitu:

1. Variasi biostarter awal dengan menggunakan kotoran sapi dan usus bekicot

2. Adanya preatreatment terhadap substrat dengan hidrolisis asam.

3. Penambahan jumlah biostarter menjadi 1 : 1 terhadap enceng gondok yang digunakan (50 g enceng gondok: $50 \mathrm{~g}$ biostarter)

\section{Prosedur Penelitian}

Penelitian ini dilakukan dengan menggunakan pengoperasian reaktor dilakukan berdasarkan urutan berikut (Saputri A.L dan Trihadiningrum, $\mathrm{Y}, 2010)$ :

1. Pada penelitian tahap 1 , substrat dengan komposisi yang sesuai, diberi perbedaan perlakuan yaitu dengan variasi biostarter $1,25 \mathrm{~g}$ kotoran sapi $(2,5 \%$ dari $50 \mathrm{~g}$ enceng gondok yang digunakan) pada reaktor TAS (tanpa Pengasaman dengan biostater 1,25 g kotoran sapi), penambahan usus bekicot pada reaktor TAB (tanpa pengasaman dengan biostater usus bekicot) dan reaktor TAK (tanpa pengasaman sebagai kontrol) sebagai kontrol tanpa penambahan apapun. Dari ketiga reaktor dengan biostarter yang paling efektif dalam menghasilkan biogas akan digunakan sebagai dasar penelitian tahap 2 . Penelitian tahap 2 diawali dengan melakukan preatreatment terhadap substrat. Substrat yang digunakan pada tahap 2 ini adalah substrat dengan komposisi yang berdasarkan hasil penelitian pendahuluan. Substrat dihidrolisis dengan menambahkan asam sulfat $\left(\mathrm{H}_{2} \mathrm{SO}_{4}\right) \quad 5 \%$ ke dalam substrat hingga mencapai $\mathrm{pH} \pm 2$. Kemudian substrat dipanaskan pada suhu $170^{\circ}$ $200^{\circ} \mathrm{C}$ selama 1 jam. Setelah dihidrolisis, substrat diberi penambahan $\mathrm{NaOH} 1 \mathrm{M}$ untuk mengembalikan $\mathrm{pH}$ susbtrat pada kisaran normal 6,8-8. Setelah pH substrat kembali normal maka selanjutnya penelitian tahap 2.

2. Pada penelitian tahap 2 ini, digunakan pula substrat tanpa proses pengasaman. Namun biostarter yang diberikan lebih banyak yaitu $50 \mathrm{~g}$ atau sebanding dengan enceng gondok yang digunakan. Penambahan jumlah biostarter pada tahap 2 ini menggunakan 2 reaktor. Rincian reaktor-reaktornya adalah sebagai berikut :

- Reaktor KS (Pengasaman dengan $50 \mathrm{~g}$ kotoran sapi).

- Reaktor SD (sustrat tanpa proses pengasaman dan diberi biostarter dengan perbandingan 1:1)

\section{Teknik Pengumpulan Data}

Teknik pengumpuan data dilakukan dengan pemantauan secara rutin setiap hari untuk aspek volume biogas total yang terbentuk dan suhu.

\section{Analisis Data}

Analisis data dilakukan terhadap biogas yang dihasilkan dan pada akhir proses dilakukan analisis COD, dan $\mathrm{pH}$ terhadap substrat dari reaktor anerobik.

\section{HASIL PENELITIAN DAN PEMBAHASAN}

\section{Penambahan Kotoran Sapi dan Usus Bekicot}

Hasil analisis terhadap biogas yang diperoleh dapat dilihat pada tabel 1 dan gambar 2. 
Tabel 1. Hasil analisis terhadap produksi biogas

\begin{tabular}{cccc}
\hline Nama Reaktor & $\begin{array}{c}\text { COD } \\
(\mathrm{mg} / \mathrm{l})\end{array}$ & $\begin{array}{c}\text { Produksi } \\
\text { Biogas }(\mathrm{mL})\end{array}$ & $\begin{array}{c}\text { Lama Pembentukan } \\
\text { Biogas (Hari) }\end{array}$ \\
\hline TAK & 19,926 & 29 & 21 \\
TAS & 25,042 & 50 & 21 \\
TAB & 21,104 & 30 & 21 \\
\hline
\end{tabular}

Keterangan:

TAK = Tanpa Pengasaman Sebagai Kontrol

TAB = Tanpa Pengasaman dengan Biostater Usus Bekicot

TAS = Tanpa Pengasaman dengan Biostater Kotoran Sapi

Tabel 1 diatas menunjukkan bahwa produksi biogas yang lebih besar terdapat pada tabung reaktor TAS (tanpa pengasaman dengan biostater kotoran sapi) yaitu sebesar $50 \mathrm{~mL}$, sedangkan pada reaktor TAK (tanpa pengasaman sebagai kontrol) sebesar 29 dan reaktor TAB (tanpa pengasaman dengan penambahan usus bekicot sebesar 30 .
Hasil yang diperoleh pada reaktor TAS atau penambahan biostater kotoran sapi dipilih untuk digunakan pada penelitian tahap selanjutnya karena biogas yang dihasilkan lebih besar dibandingkan dengan reaktor TAK dan TAB. Penambahan biostater kotoran sapi dan usus bekicot meningkatkan produksi biogas. Hal ini disebabkan karena kotoran sapi dan usus bekicot mengandung bakteri selulolitik yang dapat mendegradasi substrak enceng gondok yang banyak mengandung selulosa dan hemiselulosa (Saputri, A.R., dan Trihadiningrum, Y., 2010).

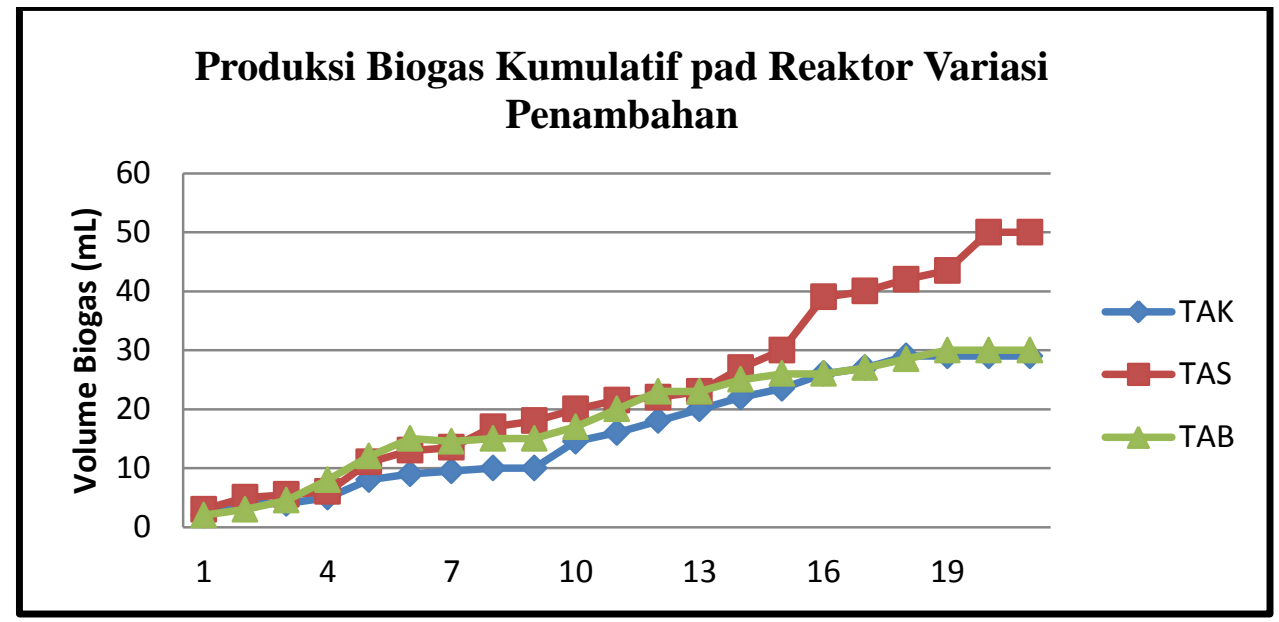

Gambar 2. Produksi biogas yang dihasilkan pada reaktor variasi penambahan biostater

Dari ketiga reaktor yang paling efektif menghasilkan biogas menjadi dasar dalam penelitian tahap 2 yaitu dengan pengasaman dan penambahan biostater. Hasil yang diperoleh ternyata yang lebih banyak menghasilkan biogas adalah dengan penambahan kotoran sapi sehingga biostater ini yang digunakan pada penelitian tahap 2 .

\section{Penambahan Asam dan Penambahan biostater}

Hasil yang diperoleh berdasarkan data hasil penelitian tahap 1 bahwa reaktor yang menghasilkan biogas lebih banyak adalah substrat enceng gondok dengan penambahan kotoran sapi. Oleh karena itu pada penelitian tahap 2 ini menggunakan enceng gondok dengan penambahan kotoran sapi dan dilakukan penambahan asam sebagai reaktor KS (kotoran sapi) dan sebagai kontrol reaktor SD (substrat tanpa penambahan kotoran sapi 1:1). Data hasil penelitian pada reaktor $\mathrm{KS}$ dan reaktor SD dapat dilihat pada tabel 2 dan gambar 3 . 
Tabel 2. Produksi Biogas Pada Reaktor penambahan biostater 1:1

\begin{tabular}{cccc}
\hline Nama Reaktor & COD $(\mathbf{m g} / \mathbf{L})$ & Produksi Biogas $(\mathbf{m L})$ & Lama Pembentukan Biogas (Hari) \\
\hline SD & 76,776 & 5 & 4 \\
KS & 36,842 & 102 & 61
\end{tabular}

Berdasarkan table 2, produksi biogas

lebih besar jika dilakukan pengasaman terhadap digunakan. Pada reaktor SD (pengasaman substrat tanpa penambahan biostater kotoran enceng gondok dan penambahan biostater yang sapi 1:1) biogas.

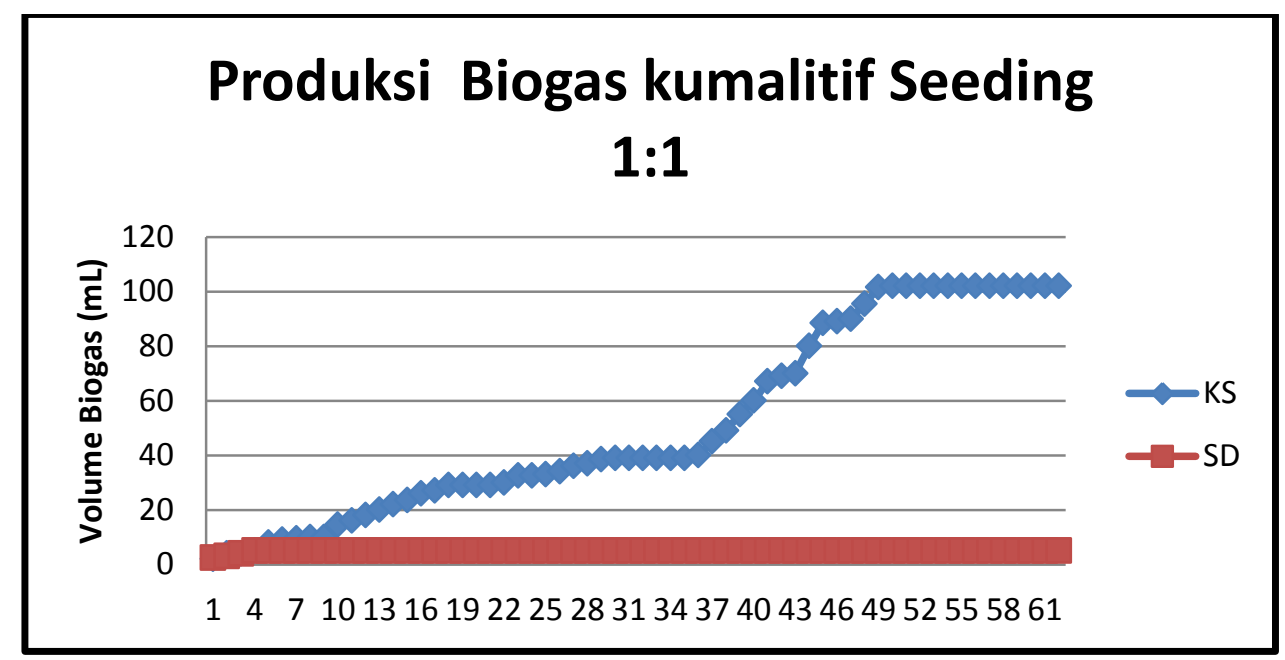

Gambar 3. Produksi Biogas Pada Reaktor Biostater 1:1

Tabel 2 dan gambar 3 menunjukkan bahwa dengan penambahan asam dan biostater dapat meningkatkan produksi biogas. Produksi biogas pada reaktor SD sangat kecil dibandingkan dengan reaktor KS.

\section{Produksi Biogas}

Produksi biogas yang dihasilkan dimonitoring tanpa melihat komposisi gas metan. Hasil pengamatan terhadap kelima reaktor yang menghasilkan biogas yang lebih besar yaitu reaktor $\mathrm{KS}$ sebesar $1,02 \mathrm{~L} / \mathrm{Kg}$ biomassa, reaktor TAS sebesar $0,5 \mathrm{~L} / \mathrm{kg}$ biomassa, reaktor TAB sebesar $0,3 \mathrm{~L} / \mathrm{Kg}$ biomassa, reaktor TAK sebesar 0,29 dan reaktor SD sebesar 0,05L/kg biomassa. Sedangkan menurut Chanakya (1993) dalam Saputri A.R. dan Trihadiningrum, Y (2010) , biogas yang dihasilkan oleh enceng gondok adalah 27,35 L/Kg biomassa.

\section{Pengaruh Penambahan Biostater Pada Pembentukan Biogas}

Penambahan biostater pada proses pembentukan biogas dapat meningkatkan produksi biogas. Kotoran sapi dan usus bekicot baik digunakan untuk biostater karena mengandung bakteri biodegradatif yang dapat memulai dan menyokong produksi biogas (Canakya, et al, 1993) dalam (Saputri A.R., Yulianti T, 2010). Bakteri yang terdapat pada kotoran sapi dan usus bekicot berupa bakteri selulolitik yang dapat meningkatkan produksi biogas sebanyak 8,4-44\% (Saputri A.R, dan Yulianti T., 2010).

Hasil penelitian yang dilakukan menunjukkan bahwa dari tiga reaktor yang digunakan pada penelitian tahap awal dengan penambahan kotoran sapi (TAS) dan usus bekicot (TAB) serta TAK (tanpa penambahan sebagai kontrol) membuktikan bahwa reaktor TAS yang memperoleh biogas lebih besar yaitu $50 \mathrm{~mL}$. Demikian juga produksi biogas yang diperoleh dari penambahan usus bekicot sebesar $30 \mathrm{~mL}$. Sedangkan reaktor kontrol lebih sedikit biogas yang dihasilkan.

\section{Pengaruh Penambahan Asam dan Penambahan Biostater Terhadap Pembentukan Biogas}

Penambahan asam pada substrat enceng gondok dimaksudkan untuk mempercepat proses pembentukan biogas. Preatreatment ini dilakukan dengan penambahan asam sulfat $\left(\mathrm{H}_{2} \mathrm{SO}_{4}\right) 5 \%$ pada substrat dan dipanaskan selama 1 jam.

Selama proses hirolisis ini, beberapa produk turunan seperti furfural, 5hidroksimetilfurfural, asam phenolic, dan beberapa aldehid, asam levulinic, dan asam alivatik lainnya dapat terbentuk dan dapat menghambat hidrolisis enzim dan fermentasi (Saosa et al., 2009) dalam (Saputri, A.R. dan Yulianti, T. 2010). Semakin lamanya pemanasan, 
maka potensi bertambahnya volume produk turunan tersebut semakin besar. Hal tersebut menjadikan pilihan hidrolisis terhadap substrat enceng gondok ini selama 1 jam.

Proses perlakukan terhadap substrat dimaksudkan agar hemiselulosa dan selulosa pada enceng gondok dapat dipecah menjadi senyawa-senyawa yang lebih sederhana sehingga lebih mudah terbentuknya biogas. Dengan demikian diharapkan dengan perlakuan ini dapat mempercepat proses pembentukan biogas.

Pembentukan biogas sangat dipengaruhi juga oleh biostater. Semakin bayak biostater yang ditambahkan maka jumlah biogas yang dihasilkan juga makin besar. Biostarter yang ditambahkan pada reaktor SD sebanyak $50 \mathrm{~g}$ kotoran sapi mempunyai jumlah mikroorganisme pengurai yang lebih banyak dari penambahan 1,25 g kotoran sapi sebelumnya. Sehingga dapat dibandingkan antara Tabel 2. dan Tabel 1. reaktor KS dapat menghasilkan 102 mL sadangkan reaktor TAS hanya $50 \mathrm{~mL}$. Sedangkan produksi biogas pada reaktor SD lebih sedikit dari hasil produksi reaktor TAK. Hal ini terjadi karena pada proses pengasaman menjadikan mikroorganisme alami terdapat pada enceng gondok sebelumnya mati, sehingga memerlukan tambahan mikroorganisme sebagai stater dalam melakukan proses fermentasi. Namun dalam reaktor SD ini tidak ditambahkan biostater. Oleh karena itu pada reaktor tersebut hanya sedikit terbentuk biogas.

\section{Perubahan Parameter-parameter pada Reaktor}

Perbedaan besarnya nilai penurunan pada setiap reaktor dipengaruhi oleh kondisi mikroorganisme pengurai pada setiap reaktor dan kondisi lingkungan pada reaktor yang sangat mempengaruhi proses. Banyaknya biostarter menambah jumlah mikroorganisme pengurai bahan organik sebagai COD, sehingga removal COD pada reaktor ini lebih besar diantara reaktor lainnya.

Penurunan konsentrasi BOD terbesar terjadi pada reaktor AS sebesar 75,05 \% karena substrat pada reaktor AS ini sudah mengalami hidrolisis lebih dulu menjadi senyawa yang lebih sederhana berupa glukosa yang mudah didegradasi oleh mikroorganisme. Penurunan BOD ini dikarenakan dimakannya atau didegradasinya bahan-bahan organik dari sampel uji oleh mikroorganisme selama proses inkubasi.

\section{KESIMPULAN}

Berdasarkan hasil penelitian yang dilakukan sebelumnya dapat disimpulkan bahwa:

1. Biomassa enceng gondok tanpa penambahan biostater dapat memproduksi biogas sebesar $29 \mathrm{~mL}$, dengan penambahan usus bekicot sebesar $30 \mathrm{~mL}$ dan penambahan kotorn sapi sebesar $50 \mathrm{~mL}$.

2. Biomassa enceng gondok dengan penambahan asam dan biostater kotoran sapi 1:1 dapat menghasilkan biogas sebesar $102 \mathrm{~mL} / \mathrm{kg}$ biomassa.

\section{DAFTAR PUSTAKA}

Abedinifer, S., K. Karimi, M. Khanahmadi, dan M. J. Taherzadeh. 2009. Ethanol Production by Mucor indicus and Rhizopus oryzae from Rice Straw by Separate Hydrolysis and Fermentation. Biomass and Energy Vol. 33 Hal. 828-833 Elsevier Ltd.

Chanakya, H.N., S. Borgaonkar, G. Meena dan K.S. Jagadish. 1993. Solid Phase Biogas Production with Garbage or Water Hyacinth. Bioresource Technology Vol. 46 Hal. 227-231

Elsevier Ltd. Chanakya, H.N., S. Borgaonkar, M. G. C. Rajan, dan M. Wahi. 1992. Two-Phase Anaerobic Digestion of Water Hyacinth or Urban Garbage. Bioresource Technology Vol. $42 \mathrm{Hal}$. 123-131 Elsevier Ltd.

Pramudono, B., Prasetya, A.R., Yonathan, A., 2004. Produksi Biogas dari Enceng gondok (Eichornia Crassipes) Kajian Konsistensi dan pH Terhadap Biogas Yang Dihasilkan

Flari, V., dan M. L. Dimitriadou. 1995. Evolution of Digestion of Carbohydrates in the Separate Parts of The Digestive Tract of The Edible Snail Helix lucorum (Gastropoda: Pulmonata: Stylommatophora) During a Complete 24-Hour Cycle and The First Days of Starvation. Journal of Comparative Physiology B: Biochemical, Systemic, and Environmental Physiology Vol. 165 Hal. 580-591 SpringerLink Berlin. 17 
Jenderal Pengolahan dan Pemasaran Hasil Pertanian. 2009. Pemanfaatan Limbah dan Kotoran Ternak menjadi Energi Biogas. Seri Bioenergi Perdesaan. Departemen Pertanian.
Saputri, A.R dan Trihadiningrum, Y. 2010. Pemanfaatan Biomassa Enceng gondok dari Kolam Greywater Sebagai Penghasil Biogas. 